Revue des sciences de l'eau

REVUEDES

Journal of Water Science

S C I E N CES

DE L'EA U

\title{
Short-term hydrological forecasts using linear regression / Prévisions hydrologiques à court terme obtenues en utilisant la régression linéaire \\ Prévisions hydrologiques à court terme obtenues en utilisant la régression linéaire
}

\section{Lefebvre}

Volume 16, numéro 2, 2003

URI : https://id.erudit.org/iderudit/705507ar

DOI : https://doi.org/10.7202/705507ar

Aller au sommaire du numéro

Éditeur(s)

Université du Québec - INRS-Eau, Terre et Environnement (INRS-ETE)

ISSN

0992-7158 (imprimé)

1718-8598 (numérique)

Découvrir la revue

Citer cet article

Lefebvre, M. (2003). Short-term hydrological forecasts using linear regression / Prévisions hydrologiques à court terme obtenues en utilisant la régression linéaire. Revue des sciences de l'eau / Journal of Water Science, 16(2), 255-277. https://doi.org/10.7202/705507ar

\section{Résumé de l'article}

On trouve qu'un modèle très simple pour le débit d'une rivière, obtenu en se servant de la régression linéaire, donne de meilleurs résultats, pendant une certaine période, qu'un modèle déterministe utilisé actuellement. Les comparaisons entre les deux modèles sont basées sur trois critères importants, à savoir le coefficient de corrélation, la somme des erreurs au carré, et le critère de pointe. Le modèle est utilisé pendant la période de crue de la rivière, et les prévisions hydrologiques sont effectuées jusqu'à trois jours d'avance. 


\section{Short-term hydrological forecasts using linear regression}

\section{Prévisions hydrologiques à court terme obtenues en utilisant la régression linéaire}

\section{LEFEBVRE}

Reçu le 16 janvier 2002, accepté le 22 novembre 2002**.

\section{RÉSUMÉ}

On trouve qu'un modèle très simple pour le débit d'une rivière, obtenu en se servant de la régression linéaire, donne de meilleurs résultats, pendant une certaine période, qu'un modèle déterministe utilisé actuellement. Les comparaisons entre les deux modèles sont basées sur trois critères importants, à savoir le coefficient de corrélation, la somme des erreurs au carré, et le critère de pointe. Le modèle est utilisé pendant la période de crue de la rivière, et les prévisions hydrologiques sont effectuées jusqu'à trois jours d'avance.

Mots clés : modélisation, loi lognormale, corrélation, erreur standard, critère de pointe.

\section{SUMMARY}

A very simple model for the flow of a river, obtained through linear regression, is found to give better results for a certain period when compared to the deterministic model currently in use. The comparisons between the two models are based on three important criteria: the correlation coefficient, the sum of the squares of the errors and the peak criterion. The model examined was used when the river was in spate and the forecasting horizon was a three-day period.

Key words: modeling, lognormal distribution, correlation, standard error, peak criterion.

Département de mathématiques et de génie industriel, École Polytechnique de Montréal, C.P. 6079 , Succursale Centre-ville, Montréal, Québec, Canada H3C 3A7. Téléphone: 514-340-4711 (poste 4947). Télécopieur: 514-340-4463. 


\section{1 - INTRODUCTION}

The Alcan company (as well as other companies in Canada) uses a deterministic model known as PREVIS (see KITE (1978), BOUCHARD and SALESSE (1986), LAUZON (1995) and LAUZON et al. (1997)) to forecast the flow of certain rivers and catchment basins. Its objective is to obtain reliable forecasts for up to seven days ahead. LABIB et al. (2000) have proposed a stochastic model for the flow based on a two-dimensional Gaussian diffusion process. They found that for one-day forecasts this model is superior to PREVIS, based on four criteria. For two-day forecasts, it is comparable to PREVIS, but it cannot compete with PREVIS for three-day forecasts. The author (see LEFEBVRE 2002a) improved the model set up from LABIB et al. (2000) and was able to obtain forecasts that were sometimes more precise than those produced by PREVIS for three days ahead (and even more). The author also considered a model derived from a one-dimensional lognormal diffusion process (see LEFEBVRE 2002b) to forecast river flows. Although this last model is more robust than that in LABIB et al. (2000) and LEFEBVRE (2002a), in that the accuracy of the forecasts deteriorates less rapidly, it could not do as well for short-term forecasts.

PREVIS needs 18 entries, such as minimum and maximum temperatures, amount of precipitation, humidity, etc., to produce its forecasts. However, if we denote the flow at time $t$ by $X(t)$, then the model in LABIB et al. (2000) requires only the knowledge of $X(t-1)$ and $X(t-2)$ to generate a forecast. In LEFEBVRE (2002a), the author first drew attention to the fact that it was more realistic to consider a lognormal rather than a Gaussian model and that it was preferable to work on a logarithmic scale when it comes to computing the various comparison criteria. The author then used linear regression, first to estimate a parameter in the model, and then to find out how to best incorporate various exogenous variables into the original model. Finally, linear regression was used in the same way in LEFEBVRE (2002b).

The objective of the papers mentioned above was to propose a simple stochastic model for the variations in flow, which possesses certain properties (such as producing Gaussian forecasts, from which confidence intervals for the forecasted flow values could be computed, for example). It was also intended to be able to make use of the stochastic model to forecast the maximum flow for a given period, as well as the first time the flow will reach a given threshold. However, the primary goal of a company such as Alcan is to receive as reliable forecasts as possible, especially for the next few days. To do so, we found out that we can obtain accurate results by making use of only two variables and linear regression.

The aim of the present paper is not to find the best possible model to forecast the flow of the Mistassibi river; but rather, to be able to predict as accurately with almost rudimentary models as with much more sophisticated models. We do not claim that a very simplistic model is always able to compete with complex ones. However, here we compare the linear regression model to a model requiring 18 entries (PREVIS) and to another model involving stochastic differential equations and diffusion processes. We found that the linear regression model produced the best hydrological forecasts. If the linear regression model had done almost as well as the other models considered, it would have already been noteworthy. 
The formulas used to make forecasts are presented in the next section, as well as the numerical results. Concluding remarks follow in Section 3.

\section{2 -FORECASTING EQUATIONS AND NUMERICAL RESULTS}

Because the availability (to us) of the forecasts produced by PREVIS was limited to the Mistassibi river in Québec for the years 1993 to 1995, we will concentrate on this river and this time period. A map of Alcan's Saguenay-LacSaint-Jean hydroelectric system, which includes the Mistassibi river, is provided at the end of this paper.

Since it is especially important to provide Alcan with reliable forecasts during the period of spate, our study will be confined to this period. In the case of the Mistassibi river, it was found (see LEFEBVRE 2002a) that the river is in spate from around the end of March until late in May. Thus, the period of interest was the 51 days from March 29th to May 18th during the years 1993-1995. Two hydrographs of the Mistassibi river for the 100-day period from March 29th to July 6th for the years 1992 and 1993 are given in figures 1 and 2 .

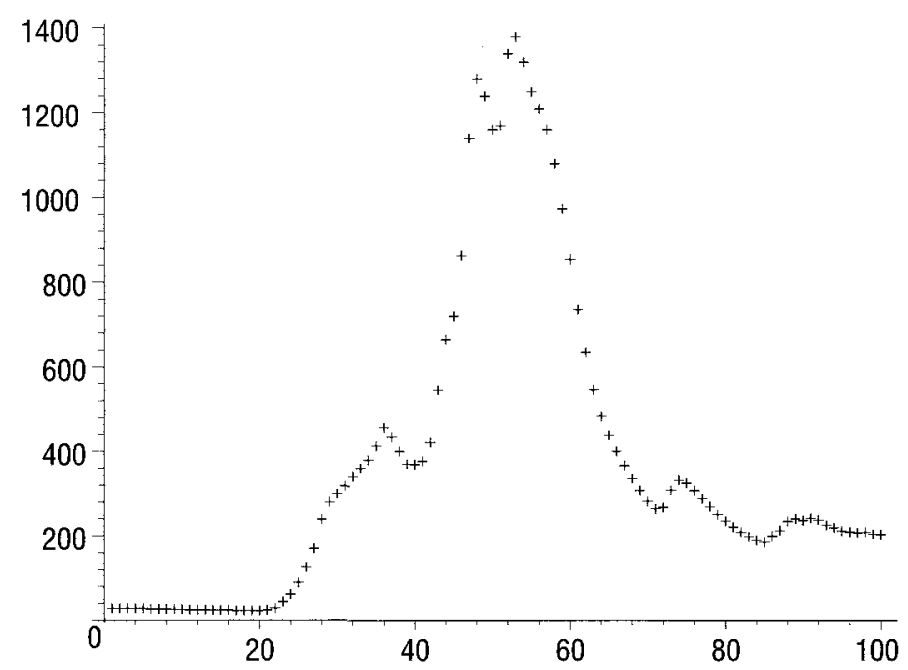

Figure $1 \quad$ Hydrograph of the Mistassibi river from March 29th to July 6th 1992.

As mentioned in the Introduction, we will work on a logarithmic scale as far as the forecasts and the computation of the various criteria are concerned. This is due to the fact that the flow of the Mistassibi river varies from around $30 \mathrm{~m}^{3} / \mathrm{s}$ 
to more than $1000 \mathrm{~m}^{3} / \mathrm{s}$ during the period of spate. Large variability in the flow can unduly influence the comparisons between the various models so that it distorts the reality.

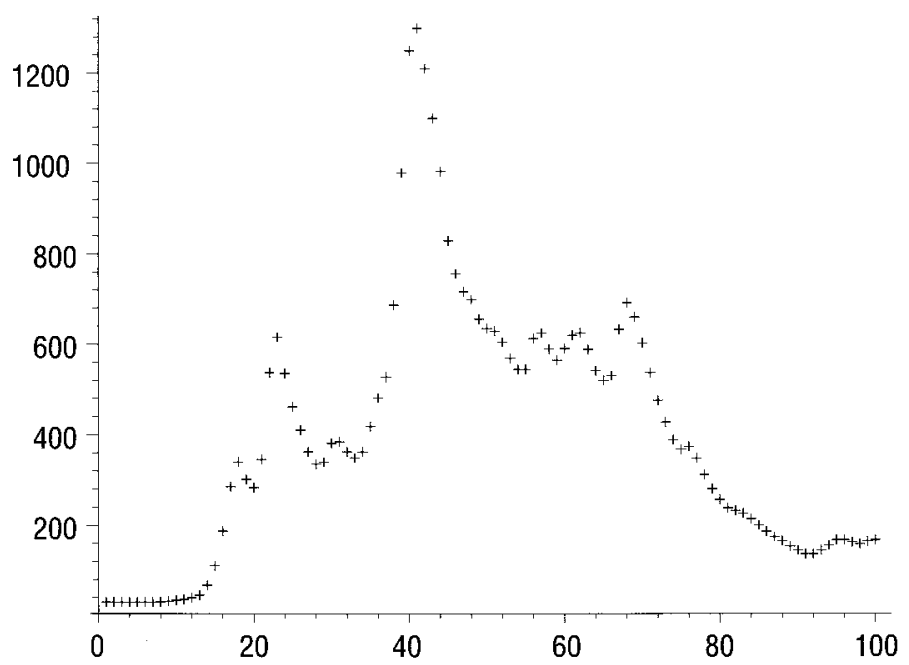

Figure 2 Hydrograph of the Mistassibi river from March 29th to July 6th 1993.

To predict the logarithm of the flow of the Mistassibi river $k$ days ahead of time $t$, we will use the following forecasting equation:

$$
\ln \widehat{X(t)}=c_{0}+c_{1} \ln X(t-k)+c_{2} \ln X(t-k-1)
$$

for $k=1,2,3$, where $X(t)$ is the observed flow at time $t$ (an instantaneous flow observed every day) and the hat denotes the predicted value. Furthermore, $c_{0}$, $c_{1}$, and $c_{2}$ are the constants obtained through linear regression.

The criteria retained to carry out the comparisons between the competing models are the same as in LABIB et al. (2000). For example, the correlation coefficient $r$ between the forecasted and observed logarithms of the flows, the sum $S S Q$ of the squares of the forecasting errors and the peak criterion defined by

$$
P C_{k}=\frac{\left[\sum_{t=1}^{N}\left(\ln \widehat{X_{k}(t)}-\ln X(t)\right)^{2} \ln ^{2} X(t)\right]^{1 / 4}}{\left[\sum_{t=1}^{N} \ln ^{2} X(t)\right]^{1 / 2}}
$$

where $N$ denotes the number of flow values greater than $1 / 3$ of the mean peak flow over the period of interest and $k$ is for the number of days ahead for which the forecast was produced. LABIB et al. (2000) used the standard error STD = $(S S Q / 50)^{1 / 2}$ rather than SSQ and they also considered a fourth criterion, namely the Nash criterion given here by : 


$$
N C_{k}=1-\frac{\sum_{t=1}^{51}\left(\ln \widehat{X_{k}(t)}-\ln X(t)\right)^{2}}{\sum_{t=1}^{51}(\ln X(t)-<\ln X(t)>)^{2}},
$$

where $<>$ denotes the mean value. It is important to note that the denominator in the previous formula does not depend on the forecasting model, therefore, the model with the best value of SSQ will also have the best Nash criterion. For this reason, this fourth criterion will not be computed in the present paper.

The forecasting equations obtained through linear regression were computed with the 255 points of data from the flood season (March 29th to May 18th) for the five-year period 1988 to 1992 (taken all at once). These results are summarized below, together with the corresponding coefficients of determination $\left(R^{2}\right)$ :

$$
\begin{aligned}
& \ln \widehat{X(t)}=0.0534+1.75 \ln X(t-1)-0.755 \ln X(t-2), R^{2} \cong 0.997 \\
& \ln \widehat{X(t)}=0.139+2.31 \ln X(t-2)-1.33 \ln X(t-3), R^{2} \cong 0.988 \\
& \ln \widehat{X(t)}=0.238+2.75 \ln X(t-3)-1.79 \ln X(t-4), R^{2} \cong 0.972
\end{aligned}
$$

\section{Remarks.}

i) The Durbin-Watson statistic, to test whether the errors are uncorrelated, was approximately 2.02 . Since there was a sampling size of 255 , we may conclude that the errors are indeed uncorrelated.

ii) We also computed the autocorrelation coefficients of the residuals for lags from 1 to 10 . They are given by: $-0.011 ;-0.060 ; 0.079 ; 0.010 ; 0.037$; $0.007 ;-0.023 ; 0.030 ;-0.069$ and -0.055 . We see that all the autocorrelation coefficients were small and there was not a pattern.

iii) Finally, the partial correlation coefficient between $\ln X(t)$ and $\ln X(t-2)$, with In $X(t-1)$ held fixed, was approximately equal to -0.735 , which is logical, given the very strong positive correlations (0.997 and 0.988$)$ between $\ln X(t)$, In $X(t-1)$ and $\ln X(t-2)$.

The performance of the forecasting equations (2)-(4), with respect to the correlation coefficient and the sum of the squares of the errors, is summarized in tables 1-3 for the years 1993 to 1995, respectively. The accuracy of the forecasts was compared to that of the forecasts produced by PREVIS and by the stochastic model proposed in LEFEBVRE (2002a) (an improvement of the model set up in LABIB et al. (2000), as mentioned above). In these tables, the subscript $L$ stands for linear regression, $S$ for the stochastic model and $P$ for PREVIS. 
Table 1 Performance of the various models for the year 1993.

Tableau 1 Performance des différents modèles pour l'année 1993.

\begin{tabular}{ccccccl}
\hline $\boldsymbol{k}$ & $\boldsymbol{r}_{\boldsymbol{L}}$ & $\boldsymbol{r}_{\boldsymbol{S}}$ & $\boldsymbol{r}_{\boldsymbol{P}}$ & $\boldsymbol{s S a}_{\boldsymbol{L}}$ & $\boldsymbol{S S Q}_{\boldsymbol{S}}$ & \multicolumn{1}{c}{$\boldsymbol{S s \boldsymbol { a } _ { \boldsymbol { P } }}$} \\
\hline 1 & 0.996 & 0.996 & 0.889 & 0.618 & 0.645 & 24.723 \\
2 & 0.980 & 0.979 & 0.872 & 3.507 & 3.834 & $17.5913^{3}$ \\
3 & 0.955 & 0.953 & 0.866 & 8.019 & 9.175 & $18.1263^{3}$ \\
\hline
\end{tabular}

Table 2 Performance of the various models for the year 1994.

Tableau 2 Performance des différents modèles pour l'année 1994.

\begin{tabular}{ccccccc}
\hline $\boldsymbol{k}$ & $\boldsymbol{r}_{\boldsymbol{L}}$ & $\boldsymbol{r}_{\boldsymbol{S}}$ & $\boldsymbol{r}_{\boldsymbol{P}}$ & $\boldsymbol{S S \boldsymbol { Q } _ { \boldsymbol { L } }}$ & $\boldsymbol{S S \boldsymbol { Q } _ { \boldsymbol { S } }}$ & $\boldsymbol{S S \boldsymbol { Q } _ { \boldsymbol { P } }}$ \\
\hline 1 & 0.998 & 0.998 & 0.994 & 0.250 & 0.251 & 1.150 \\
2 & 0.991 & 0.990 & 0.993 & 1.238 & 1.338 & 1.565 \\
3 & 0.977 & 0.976 & 0.991 & 3.039 & 3.378 & 2.087 \\
\hline
\end{tabular}

Table 3 Performance of the various models for the year 1995.

Tableau 3 Performance des différents modèles pour l'année 1995.

\begin{tabular}{ccccccc}
\hline $\boldsymbol{k}$ & $\boldsymbol{r}_{\boldsymbol{L}}$ & $\boldsymbol{r}_{\boldsymbol{S}}$ & $\boldsymbol{r}_{\boldsymbol{P}}$ & $\boldsymbol{s s a _ { \boldsymbol { L } }}$ & $\boldsymbol{s s a _ { \boldsymbol { S } }}$ & $\boldsymbol{s s a}_{\boldsymbol{P}}$ \\
\hline 1 & 0.998 & 0.998 & 0.989 & 0.252 & 0.256 & 1.461 \\
2 & 0.992 & 0.992 & 0.984 & 0.929 & 0.996 & 2.029 \\
3 & 0.981 & 0.980 & 0.979 & 2.239 & 2.381 & 2.568 \\
\hline
\end{tabular}

Looking at the numbers in tables 1-3, we must conclude that the forecasts produced by the model obtained through linear regression are the most accurate. Although the difference in the values of the correlation coefficients is sometimes rather small, the linear regression model is more accurate than the stochastic model systematically in the case of the SSQ criterion, which is the more important criterion. As for PREVIS, it had poor results in the year 1993. Actually, its performance is even worse than what appears in Table 1 because the superscripts in the $S S Q_{p}$ column denote the number of forecasts produced by PREVIS that had to be discarded because they were negative. However, in 1994 and in 1995 , PREVIS did very well. We see that neither the stochastic model nor the linear regression model was able to beat PREVIS for $k=3$ in 1994. Nevertheless, we may conclude that the linear regression model is worth considering when it comes to forecasting the Mistassibi river flows during the springtime.

It could be argued that the two criteria used so far, namely the correlation coefficient and the sum of the squares of the errors, favor the linear regression model. Due to this, we also decided to consider the peak criterion, as described above. This criterion is useful to judge the quality of the forecasts during the flood season.

In 1993, there were four peaks between March 29th and May 18th: $340 \mathrm{~m}^{3} / \mathrm{s}, 616 \mathrm{~m}^{3} / \mathrm{s}, 385 \mathrm{~m}^{3} / \mathrm{s}$ and $1300 \mathrm{~m}^{3} / \mathrm{s}$, for a mean peak flow of 
$660.25 \mathrm{~m}^{3} / \mathrm{s}$. According to the PC criterion, we must discard all the observed flows below approximately $220 \mathrm{~m}^{3} / \mathrm{s}$. Therefore, we must eliminate all the data from March 29th to April 13th, so that $N=35$ in the formula (1).

In 1994, there were two peak flows, averaging $515 \mathrm{~m}^{3} / \mathrm{s}$. This time, we had to discard the period from March 29th to April 19th, and from April 24th to April 29th, giving a value of $N$ equal to 23 .

Finally, in 1995 there were three peak flows (if we count the flow on May 18th which was the maximum flow over the entire period of interest), averaging approximately $694 \mathrm{~m}^{3} / \mathrm{s}$. We eliminated the flows from March 29th to April 23rd, thus obtaining $N=25$.

The various values of the peak criterion are shown in table 4 for the linear regression model and PREVIS. The closer to zero the numerical value is, the better the model performed.

Table $4 \quad$ Numerical values of the peak criterion for the years 1993 to 1995.

Tableau 4 Valeurs numériques du critère de pointe pour les années 1993 à 1995.

\begin{tabular}{ccccccc}
\hline & \multicolumn{2}{c}{1993} & \multicolumn{2}{c}{1994} & \multicolumn{2}{c}{1995} \\
$\boldsymbol{k}$ & $\boldsymbol{P C _ { L }}$ & $\boldsymbol{P C _ { \boldsymbol { P } }}$ & $\boldsymbol{P C _ { \boldsymbol { L } }}$ & $\boldsymbol{P C _ { \boldsymbol { P } }}$ & $\boldsymbol{P C _ { L }}$ & $\boldsymbol{P C _ { \boldsymbol { P } }}$ \\
\hline 1 & 0.05644 & 0.08705 & 0.04566 & 0.06897 & 0.04281 & 0.07332 \\
2 & 0.08646 & 0.09205 & 0.06843 & 0.07387 & 0.06827 & 0.08032 \\
3 & 0.10541 & 0.09524 & 0.08566 & 0.07863 & 0.08914 & 0.08539 \\
\hline
\end{tabular}

We see that the linear regression model performed better than PREVIS for one and two-day forecasts in every year. However, PREVIS did slightly better than the linear regression model systematically (even for 1993) for $k=3$.

Hence, the linear regression model was able to forecast flow values better than PREVIS up to two days ahead, during the period when the river flow was high, which is really important.

It is interesting to check how both models performed when we discard all the flows except the peak flows for each year and we compute the peak criterion with $N=4,2$ and 3 data, respectively. The computations were made for $k=1$ and $k=2$ and are shown in table 5 .

Table 5 The peak criterion computed with only the peak flows for the years 1993 to 1995.

Tableau 5 Le critère de pointe calculé à partir des débits de pointe seulement pour les années 1993 à 1995.

\begin{tabular}{ccccccc}
\hline & \multicolumn{2}{c}{1993} & \multicolumn{2}{c}{1994} & \multicolumn{2}{c}{1995} \\
$k$ & $P C_{L}$ & $P C_{P}$ & $P C_{L}$ & $P C_{P}$ & $P C_{L}$ & $P C_{P}$ \\
\hline 1 & 0.05382 & 0.10943 & 0.04567 & 0.06897 & 0.04325 & 0.06774 \\
2 & 0.08313 & 0.10439 & 0.06843 & 0.07387 & 0.06075 & 0.07332 \\
\hline
\end{tabular}


Again, the simple linear regression model was always better than PREVIS at forecasting peak flows one and two days ahead. However, the number of data used to compute the peak criterion was so small that we cannot state very strong conclusions.

Finally, we justified the logarithmic transformation of the data because it is recommended to use such a transformation to reduce the effect on the comparison criteria of a few poor forecasts of the flow values when the flow is very large. We could have used another transformation to attain this objective. For example, we recomputed the correlation coefficients and the sum of squares SSQ obtained with PREVIS and the linear regression model when the square root transformation was applied to the data instead. The results are presented in tables 6 and 7 for the years 1994 and 1995. We see that the conclusions are practically the same as with the logarithmic transformation.

Table 6 Performance of PREVIS and the linear regression model for the year 1994 with the square root transformation.

Tableau 6 Performance de PRÉVIS et du modèle de régression linéaire pour l'année 1994 avec la transformation racine carrée.

\begin{tabular}{ccccc}
\hline $\boldsymbol{k}$ & $\boldsymbol{r}_{\boldsymbol{L}}$ & $\boldsymbol{r}_{\boldsymbol{P}}$ & $\boldsymbol{S S \boldsymbol { Q } _ { \boldsymbol { L } }}$ & $\boldsymbol{S S \boldsymbol { Q } _ { \boldsymbol { P } }}$ \\
\hline 1 & 0.997 & 0.990 & 18.517 & 89.948 \\
2 & 0.987 & 0.988 & 86.076 & 112.89 \\
3 & 0.972 & 0.986 & 184.80 & 136.12 \\
\hline
\end{tabular}

Table 7 Performance of PREVIS and the linear regression model for the year 1995 with the square root transformation.

Tableau 7 Performance de PRÉVIS et du modèle de régression linéaire pour l'année 1995 avec la transformation racine carrée.

\begin{tabular}{ccccc}
\hline $\boldsymbol{k}$ & $\boldsymbol{r}_{\boldsymbol{L}}$ & $\boldsymbol{r}_{\boldsymbol{P}}$ & $\boldsymbol{S S \boldsymbol { Q } _ { \boldsymbol { L } }}$ & $\boldsymbol{S S \boldsymbol { Q } _ { \boldsymbol { P } }}$ \\
\hline 1 & 0.998 & 0.987 & 17.584 & 100.03 \\
2 & 0.990 & 0.983 & 79.587 & 130.08 \\
3 & 0.976 & 0.979 & 172.71 & 156.10 \\
\hline
\end{tabular}

\section{3 - CONCLUDING REMARKS}

The forecasting equations for the flow of the Mistassibi river, obtained through linear regression, gave unexpected results. The linear regression model performed better than PREVIS for one and two-day forecasts, for the three years considered, and could surely compete with PREVIS for three-day forecasts. 
In order to obtain even more accurate forecasts, various options exist. First, we could use more data (more years) to compute the forecasting equations. However, there is no guarantee that increasing the number of data would improve the accuracy of the forecasts.

Another way to improve the accuracy of the forecasts is to add at least one exogenous variable to the model, as was done in LEFEBVRE (2002a). One such variable is the temperature on the day when the flows are to be forecasted. Because this piece of information is only available to us for the years 1993 and 1994 , we had to limit ourselves to those two years. The forecasting equation for $k=1$ is the following:

$$
\ln X(t)=0.118+0.00481 T(t-1)+1.69 \ln X(t-1)-0.715 \ln X(t-2),
$$

where $T(t-1)$ is the average temperature on day $t-1$.

The values of the correlation coefficient $r$ and of the sum of squares $S S Q$ obtained with this forecasting equation are shown in Table 8.

Table 8 Performance obtained by adding temperature to the model for $k=1$ for the years 1993 and 1994.

Tableau 8 Performance obtenue en incluant la température dans le modèle pour $k=1$ pour les années 1993 et 1994 .

\begin{tabular}{ccc}
\hline & $\mathbf{1 9 9 3}$ & $\mathbf{1 9 9 4}$ \\
\hline$r$ & 0.997 & 0.998 \\
$S S Q$ & 0.5908 & 0.2493 \\
\hline
\end{tabular}

Comparing the numbers in table 8 to the corresponding ones in tables 1 and 2, we notice that the addition of the temperature to the linear regression model has had a positive effect in 1993; however, the value of SSQ in 1994 is only slightly smaller with the variable $T(t-1)$ incorporated into the model. This is probably due to the fact that the temperature is included in the flow variables. Therefore, the conclusion on the usefulness of the temperature is not clear. We could of course incorporate a different exogenous variable or more than only one exogenous variable. However, it was found in LEFEBVRE (2002a) that adding the amount of precipitation to the model had very little impact, again probably because precipitation effects are also included in the flow variables. Another explanation is that the relationships between precipitation or temperature and (the logarithm of the) flow are likely nonlinear rather than linear.

Next, we could also compute forecasting equations based on more than two values of the flow, namely the flow at time $t-1$ and at time $t-2$. We could try to measure the quality of the forecasts produced by a regression equation involving the flow at times $t-1, t-2$ and $t-3$, for example.

Finally, as was done in LEFEBVRE $(2002 a, b)$, we can consider forecasts obtained by taking the mean of the forecasts produced by PREVIS and by the linear regression model. This idea can be extended to take into account forecasts produced by any model, such as one based on neural networks. The performance of the averaged forecasts is shown in table 9 for $k=1$ and $k=2$. 
Table 9 Performance of the average forecasts for $k=1$ and $k=2$, for the years 1993 to 1995.

Tableau 9 Performance de la moyenne des prévisions pour $k=1$ et $k=2$, pour les années 1993 à 1995.

\begin{tabular}{ccccccc}
\hline & & \multicolumn{2}{c}{1993} & \multicolumn{2}{c}{1994} & \multicolumn{2}{c}{1995} \\
$k$ & $r$ & ssa & $r$ & ssa & $r$ & $s s a$ \\
\hline 1 & 0.968 & 6.171 & 0.998 & 0.325 & 0.996 & 0.488 \\
2 & 0.961 & 5.369 & 0.996 & 0.705 & 0.992 & 0.998 \\
\hline
\end{tabular}

While for $k=1$ this procedure is not recommended, essentially because the linear regression model is superior to PREVIS, we notice that for $k=2$ in 1994 the results are very impressive. The value of $S S Q$ in that case was reduced by over $43 \%$, compared with the smallest value of $S S Q$, namely $S S Q_{L}=1.238$.

In conclusion, although it is surely possible to further improve the accuracy of the forecasts, the results obtained by making use of the regression equations presented in this paper are very satisfactory. Considering the simplicity of the model, and hence its low implementation cost, it can be considered as an alternative to or as a complement to a deterministic model such as PREVIS, at least for short-term forecasting. For seven-day forecasts, the various variables PREVIS uses come into effect and help produce quite reliable forecasts. Furthermore, no probabilistic assumptions were made in this paper. Therefore, the stochastic models proposed, in particular, by LABIB et al. (2000) and by LEFEBVRE (2002a,b) have other advantages. Nevertheless, as far as the accuracy of short-term forecasts is concerned, the linear regression model is the winner.

\section{ACKNOWLEDGMENTS}

This research was supported by the Natural Sciences and Engineering Research Council of Canada. The author also expresses his gratitude to the referees of this paper for their constructive comments.

\section{REFERENCES}

BOUCHARD S., SALESSE L., 1986. Amélioration et structuration du système de prévision hydrologique à court terme PRÉVIS. Groupe de Ressources Hydrauliques, ÉÉQ, SÉCAL, Jonquière, Québec, Canada, Rapport RH-86-01, pp. 1-31.
KITE G.W., 1978. Development of a hydrological model for a Canadian watershed. Rev. Can. Génie Civ., 5, 126-134.

LABIB R., LEFEBVRE M., RIBEIRO J., ROUSSELLE J., TRUNG H.T., 2000. Application of diffusion processes to runoff estimation. J. Hydrol. Eng., 5, 1-7. 
LAUZON N., 1995. Méthodes de validation et de prévision à court terme des apports naturels. Mémoire de maîtrise, École Polytechnique, Montréal, Québec, Canada.

LAUZON N., BIRIKUNDAVYI S., GIGNAC C., ROUSSELLE J., 1997. Comparaison de deux procédures d'amélioration des prévisions à court terme des apports naturels d'un modèle déterministe. Rev. Can. Génie Civ., 24, 723-735.

LEFEBVRE M., 2002a. Using a lognormal diffusion process to forecast river flows. Water Resour. Res. (À paraître)

LEFEBVRE M., 2002b. Geometric Brownian motion as a model for river flows. Hydrol. Process., 16, 1373-1381. 


\section{Prévisions hydrologiques à court terme obtenues en utilisant la régression linéaire}

\section{Short-term hydrological forecasts using linear regression}

\section{LEFEBVRE}

Reçu le 16 janvier 2002, accepté le 22 novembre 2002, * *

\section{SUMMARY}

A very simple model for the flow of a river, obtained through linear regression, is found to give better results for a certain period when compared to the deterministic model currently in use. The comparisons between the two models are based on three important criteria: the correlation coefficient, the sum of the squares of the errors and the peak criterion. The model examined was used when the river was in spate and the forecasting horizon was a three-day period.

Key words: modeling, lognormal distribution, correlation, standard error, peak criterion.

\section{RÉSUMÉ}

On trouve qu'un modèle très simple pour le débit d'une rivière, obtenu en se servant de la régression linéaire, donne de meilleurs résultats, pendant une certaine période, qu'un modèle déterministe utilisé actuellement. Les comparaisons entre les deux modèles sont basées sur trois critères importants, à savoir le coefficient de corrélation, la somme des erreurs au carré, et le critère de pointe. Le modèle est utilisé pendant la période de crue de la rivière, et les prévisions hydrologiques sont effectuées jusqu'à trois jours d'avance.

Mots clés : modélisation, loi lognormale, corrélation, erreur standard, critère de pointe.

Département de mathématiques et de génie industriel, École Polytechnique de Montréal, C.P. 6079 , Succursale Centre-ville, Montréal, Québec, Canada H3C 3A7. Téléphone: 514-340-4711 (poste 4947). Télécopieur: 514-340-4463. 


\section{1 - INTRODUCTION}

L'entreprise Alcan (ainsi que d'autres entreprises au Canada) utilise un modèle déterministe appelé PRÉVIS (voir KITE (1978), BOUCHARD et SALESSE (1986), LAUZON (1995) et LAUZON et al. (1997)) pour prévoir le débit de certaines rivières et bassins hydrographiques. Son objectif est d'obtenir des prévisions fiables jusqu'à sept jours d'avance. LABIB et al. (2000) ont proposé un modèle stochastique pour le débit, basé sur un processus de diffusion gaussien bidimensionnel. Ils ont trouvé que, pour des prévisions un jour d'avance, ce modèle est supérieur à PRÉVIS, par rapport à quatre critères. Pour des prévisions deux jours d'avance, il est comparable à PRÉVIS, mais il ne peut pas rivaliser avec PRÉVIS à partir de prévisions trois jours d'avance. L'auteur (voir LEFEBVRE 2002a) a amélioré le modèle développé dans LABIB et al. (2000) et a réussi à obtenir des prévisions qui étaient parfois plus précises que celles produites par PRÉVIS pour trois jours d'avance (et même plus). L'auteur a aussi considéré un modèle basé sur un processus de diffusion lognormal unidimensionnel (voir LEFEBVRE 2002b) pour prévoir les débits d'une rivière; quoique ce dernier modèle soit plus robuste que celui dans LABIB et al. (2000) et LEFEBVRE (2002a), en ce sens que la précision des prévisions se détériore moins rapidement, il ne pouvait pas faire aussi bien pour des prévisions à court terme.

PRÉVIS a besoin de 18 entrées, telles que les températures minimale et maximale, la quantité de précipitations, l'humidité, etc., pour produire ses prévisions. D'un autre côté, si l'on dénote le débit à l'instant $t$ par $X(t)$, alors dans le cas du modèle dans LABIB et al. (2000), il suffit de connaître $X(t-1)$ et $X(t-2)$ pour générer une prévision. Dans LEFEBVRE (2002a), l'auteur a fait remarquer qu'il était plus réaliste de considérer un modèle lognormal plutôt qu'un modèle gaussien, et qu'il était préférable de travailler sur une échelle logarithmique lorsqu'on calcule les divers critères de comparaison. L'auteur a ensuite utilisé la régression linéaire, d'abord pour estimer un paramètre dans le modèle, puis pour trouver la meilleure façon d'incorporer diverses variables exogènes dans le modèle original. Finalement, la régression linéaire a été utilisée de la même façon dans LEFEBVRE (2002b).

L'objectif dans les articles mentionnés ci-dessus était de proposer un modèle stochastique simple, pour les variations du débit, qui possède des propriétés intéressantes (par exemple, un modèle qui produit des prévisions gaussiennes, à partir desquelles des intervalles de confiance pourraient être calculés pour les débits prévus). On voulait aussi pouvoir se servir du modèle stochastique pour prévoir le débit maximal pendant une période donnée ainsi que le temps requis pour que le débit dépasse un seuil fixé. Cependant, le but premier d'une entreprise telle que I'Alcan est de recevoir des prévisions aussi fiables que possible, en particulier à quelques jours d'avis. Pour ce faire, nous avons trouvé que l'on peut obtenir des résultats vraiment excellents en n'utilisant que deux variables et la régression linéaire.

Le but du présent article n'est pas de trouver le meilleur modèle possible pour prévoir le débit de la rivière Mistassibi; on désire plutôt montrer qu'il est parfois possible de faire aussi bien avec des modèles presque rudimentaires qu'avec des modèles beaucoup plus perfectionnés. Nous ne prétendons pas qu'un modèle très simple peut toujours rivaliser avec des modèles complexes. 
Cependant, ici nous comparons le modèle de régression linéaire à un modèle qui utilise 18 entrées (PRÉVIS) et à un autre qui fait appel aux équations différentielles stochastiques et aux processus de diffusion, et l'on trouve que le modèle de régression linéaire produit de meilleures prévisions hydrologiques à court terme. Si le modèle de régression linéaire avait fait presque aussi bien que les autres modèles considérés, cela aurait déjà été remarquable.

Les formules utilisées pour produire les prévisions ainsi que les résultats numériques sont présentés dans la section qui suit. À la section 3 , des remarques concluent cet article.

\section{2 - ÉQUATIONS DE PRÉVISION ET RÉSULTATS NUMÉRIQUES}

Parce que nous ne disposons que des prévisions produites par PRÉVIS pour la rivière Mistassibi, au Québec, et ce, pour les années 1993 à 1995, nous allons nous limiter à cette rivière et à ces années. Une carte du système hydroélectrique Saguenay-Lac-Saint-Jean de I'Alcan, qui inclut la rivière Mistassibi, est fournie à la fin de cet article.

Étant donné qu'il est spécialement important de fournir à l'Alcan des prévisions fiables durant la période de crue de la rivière, notre étude portera exclusivement sur cette période. Dans le cas de la rivière Mistassibi, on a trouvé (voir LEFEBVRE (2002b)) que la rivière est en crue à partir d'environ la fin de mars jusqu'à tard en mai. De façon plus précise, la période d'intérêt sera les 51 jours à partir du 29 mars jusqu'au 18 mai, pour chacune des années 1993 à 1995. Les figures 1 et 2 présentent deux hydrogrammes de la rivière Mistassibi pour la période de 100 jours du 29 mars au 6 juillet pour les années 1992 et 1993.

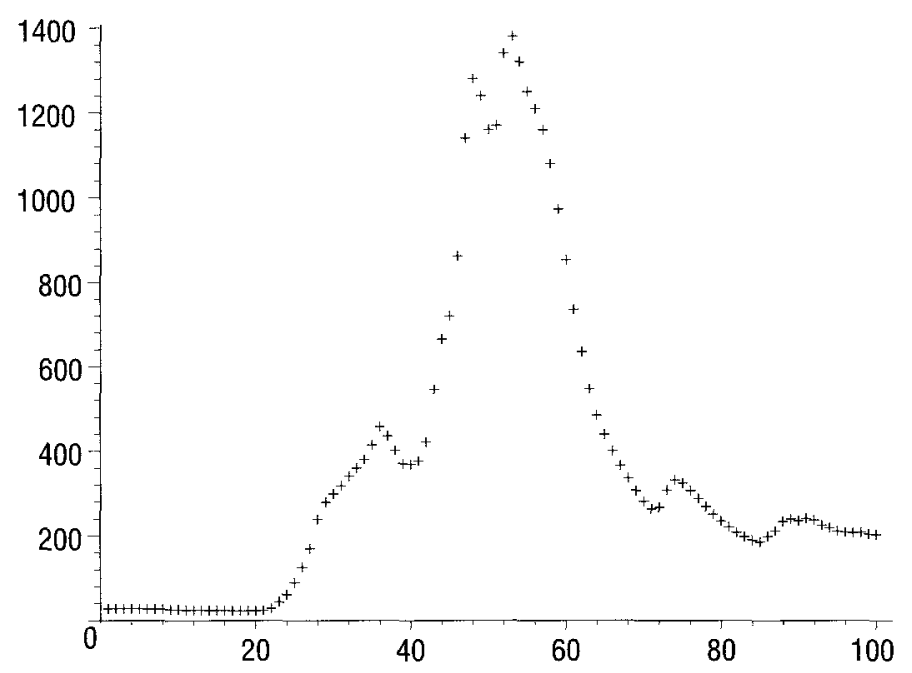

Figure 1 Hydrogramme de la rivière Mistassibi du 29 mars au 6 juillet 1992.

Hydrograph of the Mistassibi river from March 29th to July 6th 1992. 


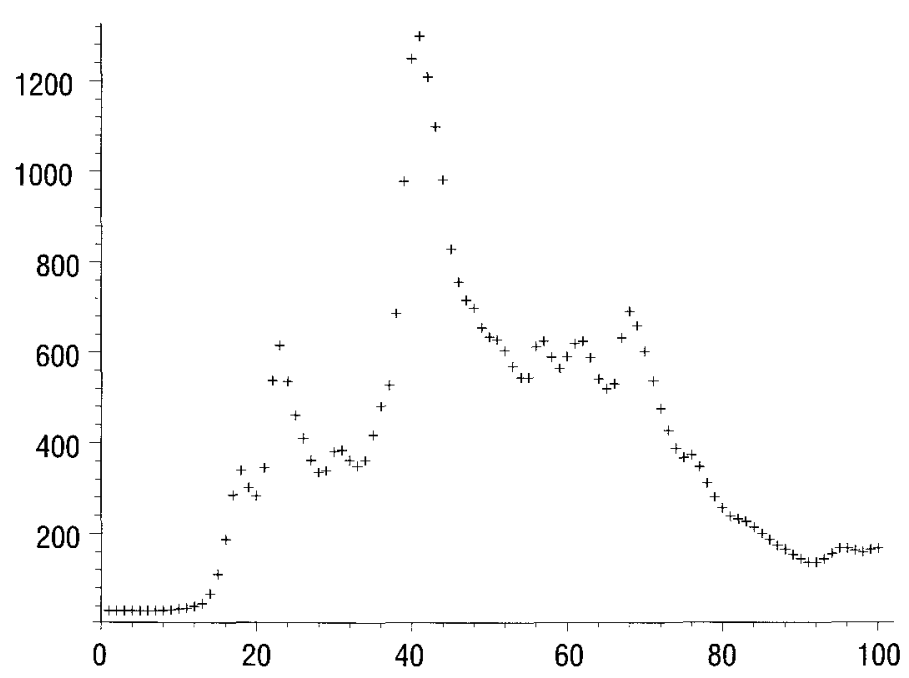

Figure 2 Hydrogramme de la rivière Mistassibi du 29 mars au 6 juillet 1993.

Hydrograph of the Mistassibi river from March 29th to July 6th 1993.

Tel que mentionné dans l'introduction, nous allons travailler sur une échelle logarithmique pour le calcul des prévisions et des divers critères de comparaison. Cela est dû au fait que le débit de la rivière Mistassibi varie d'environ $30 \mathrm{~m}^{3} / \mathrm{s}$ à plus de $1000 \mathrm{~m}^{3} / \mathrm{s}$ pendant sa période de crue. Dans un tel cas, seulement quelques mauvaises prévisions du débit, lorsqu'il est très grand, peuvent influencer indûment les comparaisons entre les divers modèles considérés, de sorte que cela peut fausser les résultats.

Pour prévoir le logarithme du débit de la rivière Mistassibi $k$ jours avant le jour $t$, nous allons nous servir de l'équation de prévision suivante:

$$
\ln \widehat{X(t)}=c_{0}+c_{1} \ln X(t-k)+c_{2} \ln X(t-k-1)
$$

pour $k=1,2,3$, où $X(\mathrm{t})$ est le débit observé le jour $t$ (un débit instantané observé chaque jour) et le chapeau dénote la valeur prévue. De plus, $c_{0}, c_{1}$ et $c_{2}$ sont des constantes obtenues en utilisant la régression linéaire.

Les critères utilisés pour comparer les modèles considérés sont les mêmes que ceux dans LABIB et al. (2000) : le coefficient de corrélation $r$ des logarithmes des débits prévus et observés, la somme $S S Q$ des carrés des erreurs de prévision et le critère de pointe défini par

$$
P C_{k}=\frac{\left[\sum_{t=1}^{N}\left(\ln \widehat{X_{k}(t)}-\ln X(t)\right)^{2} \ln ^{2} X(t)\right]^{1 / 4}}{\left[\sum_{t=1}^{N} \ln ^{2} X(t)\right]^{1 / 2}}
$$


où $N$ dénote le nombre de valeurs du débit supérieures à $1 / 3$ du débit de pointe moyen pendant la période d'intérêt et $k$ est le nombre de jours d'avance par rapport à $t$ lorsque la prévision a été produite. En fait, LABIB et al. (2000) ont utilisé l'erreur standard STD $=(S S Q / 50)^{1 / 2}$ plutôt que SSQ. Ils ont aussi considéré un quatrième critère, soit le critère de Nash donné ici par

$$
N C_{k}=1-\frac{\sum_{t=1}^{51}\left(\ln \widehat{X_{k}(t)}-\ln X(t)\right)^{2}}{\sum_{t=1}^{51}(\ln X(t)-<\ln X(t)>)^{2}},
$$

où $<>$ désigne la valeur moyenne. Remarquons cependant que le dénominateur dans la formule précédente ne dépend pas du modèle de prévision. Par conséquent, le modèle qui possède la meilleure valeur de SSQ possédera aussi la meilleure valeur du critère de Nash. Pour cette raison, ce quatrième critère ne sera pas calculé dans cet article.

Les équations de prévision obtenues en utilisant la régression linéaire ont été calculées avec les 255 données des périodes de crue (29 mars au 18 mai) des années 1988 à 1992 (prises toutes à la fois) et sont données ci-dessous, ainsi que les coefficients de détermination $R^{2}$ correspondants :

$$
\begin{aligned}
& \ln \widehat{X(t)}=0,0534+1,75 \ln X(t-1)-0,755 \ln X(t-2), R^{2} \cong 0,997 \\
& \ln \widehat{X(t)}=0,139+2,31 \ln X(t-2)-1,33 \ln X(t-3), R^{2} \cong 0,988 \\
& \ln \widehat{X(t)}=0,238+2,75 \ln X(t-3)-1,79 \ln X(t-4), R^{2} \cong 0,972
\end{aligned}
$$

\section{Remarques.}

i) La statistique de Durbin-Watson utilisée pour tester si les erreurs sont non corrélées est environ égale à 2,02. Puisqu'il y a 255 données, on peut effectivement conclure que les erreurs sont non corrélées.

ii) Nous avons aussi calculé les coefficients d'autocorrélation des résidus pour des pas allant de 1 à 10 . Ils sont donnés par : $-0,011 ;-0,060 ; 0,079$; 0,$010 ; 0,037 ;-0,007 ;-0,023 ; 0,030 ;-0,069 ;-0,055$. On voit qu'ils sont tous petits et ne suivent aucune tendance particulière.

iii) Finalement, le coefficient de corrélation partielle de $\ln X(t)$ et $\ln X(t-2)$, lorsque In $X(t-1)$ est gardé constant, est approximativement égal à $-0,735$, ce qui est logique, étant donné les corrélations positives très fortes $(0,997$ et $0,988)$ entre $\ln X(t), \ln X(t-1)$ et $\ln X(t-2)$.

La performance des équations de prévision (2)-(4), en ce qui concerne le coefficient de corrélation et la somme des carrés des erreurs, est résumée dans les tableaux 1-3 pour les années 1993-1995, respectivement. La précision des prévisions est comparée à celle des prévisions produites par PRÉVIS et par le modèle stochastique proposé dans LEFEBVRE (2002a), lequel est une amélioration du modèle développé dans LABIB et al. (2000), tel que mentionné ci-dessus. Dans ces tableaux, l'indice $L$ est utilisé pour le modèle de régression linéaire, $S$ pour le modèle stochastique et $P$ pour PRÉVIS. 
Tableau 1 Performance des différents modèles pour l'année 1993.

Table 1 Performance of the various models for the year 1993.

\begin{tabular}{|c|c|c|c|c|c|c|}
\hline$k$ & $r_{L}$ & $r_{s}$ & $r_{p}$ & $s s a_{L}$ & $s s a_{s}$ & $s \mathbf{S O}_{p}$ \\
\hline 1 & 0,996 & 0,996 & 0,889 & 0,618 & 0,645 & 24,723 \\
\hline 2 & 0,980 & 0,979 & 0,872 & 3,507 & 3,834 & $17,5913^{3}$ \\
\hline 3 & 0,955 & 0,953 & 0,866 & 8,019 & 9,175 & $18,1263^{3}$ \\
\hline
\end{tabular}

Tableau 2 Performance des différents modèles pour l'année 1994.

Table 2 Performance of the various models for the year 1994.

\begin{tabular}{ccccccc}
\hline $\boldsymbol{k}$ & $\boldsymbol{r}_{\boldsymbol{L}}$ & $\boldsymbol{r}_{\boldsymbol{S}}$ & $\boldsymbol{r}_{\boldsymbol{P}}$ & $\boldsymbol{s s a _ { \boldsymbol { L } }}$ & $\boldsymbol{s s a _ { \boldsymbol { S } }}$ & $\boldsymbol{s s a}_{\boldsymbol{P}}$ \\
\hline $\mathbf{1}$ & 0,998 & 0,998 & 0,994 & 0,250 & 0,251 & 1,150 \\
2 & 0,991 & 0,990 & 0,993 & 1,238 & 1,338 & 1,565 \\
3 & 0,977 & 0,976 & 0,991 & 3,039 & 3,378 & 2,087 \\
\hline
\end{tabular}

Tableau 3 Performance des différents modèles pour l'année 1995.

Table 3 Performance of the various models for the year 1995.

\begin{tabular}{ccccccc}
\hline $\boldsymbol{k}$ & $\boldsymbol{r}_{\boldsymbol{L}}$ & $\boldsymbol{r}_{\boldsymbol{S}}$ & $\boldsymbol{r}_{\boldsymbol{P}}$ & $\boldsymbol{s} \boldsymbol{s \boldsymbol { a } _ { \boldsymbol { L } }}$ & $\boldsymbol{s s \boldsymbol { a } _ { \boldsymbol { S } }}$ & $\boldsymbol{s \boldsymbol { s } \boldsymbol { Q } _ { \boldsymbol { P } }}$ \\
\hline 1 & 0,998 & 0,998 & 0,989 & 0,252 & 0,256 & 1,461 \\
2 & 0,992 & 0,992 & 0,984 & 0,929 & 0,996 & 2,029 \\
3 & 0,981 & 0,980 & 0,979 & 2,239 & 2,381 & 2,568 \\
\hline
\end{tabular}

En regardant les nombres dans les tableaux 1-3, nous devons conclure que les prévisions produites par le modèle obtenu en se servant de la régression linéaire sont les plus précises. Quoique la différence entre les valeurs des coefficients de corrélation soit parfois faible, le modèle de régression linéaire l'emporte sur le modèle stochastique de façon systématique dans le cas du critère $S S Q$, qui est en fait le critère le plus important. En ce qui concerne PRÉVIS, il a obtenu de très mauvais résultats en 1993. En fait, sa performance est même pire que ce qui apparaît dans le tableau 1, car les exposants dans la colonne $S S Q_{P}$ dénotent le nombre de prévisions produites par PRÉVIS dont on a dû ne pas tenir compte parce qu'elles étaient négatives (!). Par contre, en 1994 (particulièrement) et en 1995, PRÉVIS a très bien fait. On voit que ni le modèle stochastique ni le modèle de régression linéaire n'ont pu battre PRÉVIS pour $k=3$ en 1994. Néanmoins, on peut conclure que le modèle de régression linéaire mérite certainement d'être considéré pour la prévision du débit de la rivière Mistassibi pendant la saison printanière.

Maintenant, on pourrait prétendre que les deux critères que l'on a utilisés jusqu'ici, soit le coefficient de corrélation et la somme des carrés des erreurs, favorisent le modèle de régression linéaire. À cause de cela, nous avons décidé de considérer également le critère de pointe, tel que décrit ci-dessus. Ce critère est utile pour mesurer la qualité des prévisions durant la période de crue. 
En 1993, il y a eu quatre débits de pointe du 29 mars au 18 mai: $340 \mathrm{~m}^{3} / \mathrm{s}$, $616 \mathrm{~m}^{3} / \mathrm{s}, 385 \mathrm{~m}^{3} / \mathrm{s}$ et $1300 \mathrm{~m}^{3} / \mathrm{s}$, pour un débit de pointe moyen de $660,25 \mathrm{~m}^{3} / \mathrm{s}$. Selon la définition du critère $P C$, nous devons éliminer tous les débits observés du 29 mars au 13 avril, de sorte que $N=35$ dans la formule (1).

En 1994, il n'y a eu que deux débits de pointe, dont la moyenne est égale à $515 \mathrm{~m} 3 / \mathrm{s}$. Cette fois-ci, nous avons dû éliminer la période du 29 mars au 19 avril, et celle du 24 au 29 avril, nous donnant une valeur de $N$ égale à 23 .

Finalement, en 1995 on a observé trois débits de pointe (si l'on compte le débit du 18 mai, lequel fut le débit maximal observé pendant toute la période d'intérêt), dont la moyenne est environ égale à $694 \mathrm{~m}^{3} / \mathrm{s}$. Nous avons éliminé les débits du 29 mars au 23 avril, de sorte que $N=25$.

Les diverses valeurs du critère de pointe sont présentées dans le tableau 4 pour le modèle de régression linéaire et pour PRÉVIS. L'objectif est d'avoir une valeur numérique la plus proche de 0 possible.

Tableau 4 Valeurs numériques du critère de pointe pour les années 1993 à 1995.

Table $4 \quad$ Numerical values of the peak criterion for the years 1993 to 1995.

\begin{tabular}{ccccccc}
\hline & \multicolumn{2}{c}{1993} & \multicolumn{2}{c}{1994} & \multicolumn{2}{c}{1995} \\
$\boldsymbol{k}$ & $\boldsymbol{P C _ { \boldsymbol { L } }}$ & $\boldsymbol{P C _ { \boldsymbol { P } }}$ & $\boldsymbol{P C _ { \boldsymbol { L } }}$ & $\boldsymbol{P \boldsymbol { C } _ { \boldsymbol { P } }}$ & $\boldsymbol{P \boldsymbol { C } _ { \boldsymbol { L } }}$ & $\boldsymbol{P \boldsymbol { C } _ { \boldsymbol { P } }}$ \\
\hline 1 & 0,05644 & 0,08705 & 0,04566 & 0,06897 & 0,04281 & 0,07332 \\
2 & 0,08646 & 0,09205 & 0,06843 & 0,07387 & 0,06827 & 0,08032 \\
3 & 0,10541 & 0,09524 & 0,08566 & 0,07863 & 0,08914 & 0,08539 \\
\hline
\end{tabular}

On voit que le modèle de régression linéaire l'emporte sur PRÉVIS chaque année pour des prévisions un et deux jours d'avance. Toutefois, PRÉVIS a fait un peu mieux que le modèle de régression linéaire de façon systématique (même en 1993!) pour $k=3$.

Donc, le modèle de régression linéaire a réussi à prévoir les valeurs du débit mieux que PRÉVIS jusqu'à deux jours d'avance lorsque le débit de la rivière était élevé, ce qui est vraiment important.

II est intéressant de regarder comment se comportent les deux modèles lorsqu'on élimine tous les débits, excepté les débits de pointe pour chaque année, et I'on calcule le critère de pointe avec $N=4,2$ et 3 données, respectivement. Les calculs ont été faits pour $k=1$ et $k=2$ et sont présentés dans le tableau 5 .

Tableau 5 Le critère de pointe calculé à partir des débits de pointe seulement pour les années 1993 à 1995.

Table 5 The peak criterion computed with only the peak flows for the years 1993 to 1995.

\begin{tabular}{ccccccc}
\hline & \multicolumn{2}{c}{1993} & \multicolumn{2}{c}{1994} & \multicolumn{2}{c}{1995} \\
$\boldsymbol{k}$ & $\boldsymbol{P C _ { L }}$ & $\boldsymbol{P C _ { P }}$ & $\boldsymbol{P C _ { L }}$ & $\boldsymbol{P C _ { \boldsymbol { P } }}$ & $\boldsymbol{P C _ { L }}$ & $\boldsymbol{P C _ { \boldsymbol { P } }}$ \\
\hline 1 & 0,05382 & 0,10943 & 0,04567 & 0,06897 & 0,04325 & 0,06774 \\
2 & 0,08313 & 0,10439 & 0,06843 & 0,07387 & 0,06075 & 0,07332 \\
\hline
\end{tabular}


Encore une fois, le modèle de régression linéaire réussit à mieux prévoir les débits de pointe que PRÉVIS un et deux jours d'avance. Cependant, le nombre de données utilisées pour calculer le critère de pointe est si petit que I'on ne peut pas tirer des conclusions générales très fortes.

Finalement, nous avons justifié la transformation logarithmique des données en affirmant qu'il est recommandé d'effectuer une telle transformation pour réduire l'effet sur les critères de comparaison de quelques mauvaises prévisions des débits lorsque ce débit est très grand. Nous aurions pu nous servir d'une autre transformation pour réaliser cet objectif. Par exemple, nous avons recalculé les coefficients de corrélation et la somme des carrés SSQ obtenus avec PRÉVIS et le modèle de régression linéaire lorsqu'on a transformé les données en prenant leur racine carrée. Les tableaux 6 et 7 présentent les résultats pour les années 1994 et 1995, respectivement. On constate que les conclusions sont pratiquement les mêmes qu'avec la transformation logarithmique.

Tableau 6 Performance de PRÉVIS et du modèle de régression linéaire pour l'année 1994 avec la transformation racine carrée.

Table 6 Performance of PREVIS and the linear regression model for the year 1994 with the square root transformation.

\begin{tabular}{ccccc}
\hline $\boldsymbol{k}$ & $\boldsymbol{r}_{\boldsymbol{L}}$ & $\boldsymbol{r}_{\boldsymbol{P}}$ & $\boldsymbol{S S a}_{\boldsymbol{L}}$ & $\boldsymbol{S s a}_{\boldsymbol{p}}$ \\
\hline 1 & 0,997 & 0,990 & 18,517 & 89,948 \\
2 & 0,987 & 0,988 & 86,076 & 112,89 \\
3 & 0,972 & 0,986 & 184,80 & 136,12 \\
\hline
\end{tabular}

Tableau 7 Performance de PRÉVIS et du modèle de régression linéaire pour l'année 1995 avec la transformation racine carrée.

Table 7 Performance of PREVIS and the linear regression model for the year 1995 with the square root transformation.

\begin{tabular}{ccccc}
\hline $\boldsymbol{k}$ & $\boldsymbol{r}_{\boldsymbol{L}}$ & $\boldsymbol{r}_{\boldsymbol{P}}$ & $\boldsymbol{s} \boldsymbol{s \boldsymbol { a } _ { \mathbf { L } }}$ & $\boldsymbol{s} \boldsymbol{s \boldsymbol { a } _ { \boldsymbol { P } }}$ \\
\hline 1 & 0,998 & 0,987 & 17,584 & 100,03 \\
2 & 0,990 & 0,983 & 79,587 & 130,08 \\
3 & 0,976 & 0,979 & 172,71 & 156,10 \\
\hline
\end{tabular}

\section{3 - REMARQUES DE CONCLUSION}

Les équations de prévision pour le débit de la rivière Mistassibi, au Québec, obtenues en se servant de la régression linéaire, ont donné des résultats inespérés. En effet, le modèle de régression linéaire a mieux fait que PRÉVIS 
pour des prévisions un et deux jours d'avance, et ce, pour les trois années considérées, et peut certainement rivaliser avec PRÉVIS pour des prévisions trois jours d'avance.

Pour obtenir des prévisions encore plus précises, il existe plusieurs possibilités. D'abord, on pourrait se servir de plus de données (c'est-à-dire d'années) pour calculer les équations de prévision. Toutefois, rien ne nous assure qu'augmenter le nombre de données améliorerait la qualité des prévisions hydrologiques. Cela pourrait même avoir l'effet contraire.

Une autre façon d'augmenter la précision des prévisions est d'inclure au moins une variable exogène dans le modèle, comme dans LEFEBVRE (2002a). Une variable exogène importante est la température le jour où l'on prévoit les débits. Nous avons dû limiter notre étude aux années 1993 et 1994, soit les seules années pour lesquelles nous disposons de cette information. L'équation de prévision pour $k=1$ est la suivante :

$$
\ln \widehat{X(t)}=0,118+0,00481 T(t-1)+1,69 \ln X(t-1)-0,715 \ln X(t-2),
$$

où $T(t-1)$ est la température moyenne lors du jour $t-1$.

Les valeurs du coefficient de corrélation $r$ et de la somme des carrés $S S Q$ obtenues avec cette équation de prévision apparaissent dans le tableau 8.

Tableau 8 Performance obtenue en incluant la température dans le modèle pour $k=1$ pour les années 1993 et 1994 .

Table 8 Performance obtained by adding temperature to the model for $k=1$ for the years 1993 and 1994.

\begin{tabular}{ccc}
\hline & 1993 & 1994 \\
\hline$r$ & 0,997 & 0,998 \\
$S S Q$ & 0,5908 & 0,2493 \\
\hline
\end{tabular}

En comparant les nombres dans ce tableau aux nombres correspondants dans les tableaux 1 et 2 , on remarque que l'ajout de la température dans le modèle de régression linéaire a eu un effet positif en 1993 ; cependant, la valeur de $S S Q$ en 1994 n'est que légèrement inférieure avec la variable $T(t-1)$ incorporée dans le modèle, probablement parce que la température est déjà incluse dans les variables de débit. Par conséquent, la conclusion quant à l'utilité de la température $\mathrm{n}^{\mathrm{I}}$ est pas claire. On pourrait naturellement ajouter une variable exogène différente, ou plus d'une variable exogène. Toutefois, on a trouvé dans LEFEBVRE (2002a) que l'incorporation de la quantité de précipitations (par exemple) dans le modèle avait très peu d'impact, encore une fois probablement parce que l'effet des précipitations est aussi inclus dans les variables de débit. Une autre explication est que la relation entre les précipitations ou la température et le (logarithme du) débit sont probablement non linéaires plutôt que linéaires.

Ensuite, on pourrait aussi calculer les équations de prévision en se basant sur plus de deux valeurs du débit, soit le débit à $t-1$ et à $t-2$. On pourrait, par exemple, essayer de mesurer la qualité des prévisions produites par une équation de régression calculée avec les débits à $t-1, t-2$ et $t-3$. 
Finalement, comme on l'a fait dans LEFEBVRE (2002a,b), on pourrait considérer les prévisions obtenues en prenant la moyenne des prévisions produites par PRÉVIS et par le modèle de régression linéaire. Cette idée peut être généralisée pour tenir compte des prévisions produites par n'importe quel modèle, par exemple un modèle basé sur les réseaux de neurones. La performance des prévisions moyennes est présentée dans le tableau 9 pour $k=1$ et $k=2$.

Tableau 9 Performance de la moyenne des prévisions pour $k=1$ et $k=2$, pour les années 1993 à 1995.

Table 9 Performance of the average forecasts for $k=1$ and $k=2$, for the years 1993 to 1995.

\begin{tabular}{ccccccc}
\hline & & \multicolumn{2}{c}{1993} & \multicolumn{2}{c}{1994} & \multicolumn{2}{c}{1995} \\
$k$ & $r$ & ssa & $r$ & ssQ & $r$ & $s s Q$ \\
\hline 1 & 0,968 & 6,171 & 0,998 & 0,325 & 0,996 & 0,488 \\
2 & 0,961 & 5,369 & 0,996 & 0,705 & 0,992 & 0,998 \\
\hline
\end{tabular}

Si pour $k=1$ cette procédure n'est pas recommandée, essentiellement parce que le modèle de régression linéaire est tellement supérieur à PRÉVIS pour cette valeur de $k$, on remarque que pour $k=2$ en 1994 les résultats sont très impressionnants. En effet, la valeur de $S S Q$ dans ce cas a été réduite de plus de $43 \%$, par rapport à la plus petite valeur de $S S Q$, soit $S S Q_{L}=1,238$.

En conclusion, quoiqu'il soit sûrement possible d'améliorer encore plus la précision des prévisions, les résultats obtenus en se servant de la régression linéaire et présentés dans cet article sont très satisfaisants. En considérant sa simplicité, et de là son faible coût de mise en œuvre, ce modèle peut être considéré comme un concurrent, ou plutôt, comme un complément d'un modèle déterministe comme PRÉVIS, au moins pour des prévisions à court terme. Pour des prévisions sept jours d'avance, par exemple, les diverses variables auxquelles PRÉVIS fait appel entrent en jeu et aident à produire des prévisions relativement fiables. De plus, aucune hypothèse probabiliste n'a été faite dans cet article. Par conséquent, les modèles stochastiques proposés, en particulier, par LABIB et al. (2000) et par LEFEBVRE $(2002 a, b)$ ont d'autres avantages. Néanmoins, en ce qui concerne la précision des prévisions à court terme, le modèle de régression linéaire l'emporte sur ses concurrents.

\section{REMERCIEMENTS}

Recherche subventionnée par le Conseil de recherches en sciences naturelles et en génie du Canada. L'auteur désire aussi remercier les réviseurs de cet article pour leurs commentaires constructifs. 


\section{RÉFÉRENCES BIBLIOGRAPHIQUES}

BOUCHARD S., SALESSE L., 1986. Amélioration et structuration du système de prévision hydrologique à court terme PRÉVIS. Groupe de Ressources Hydrauliques, ÉÉQ, SÉCAL, Jonquière, Québec, Canada, Rapport RH-86-01, pp. 1-31.

KITE G.W., 1978. Development of a hydrological model for a Canadian watershed. Rev. Can. Génie Civ., 5, 126-134.

LABIB R., LEFEBVRE M., RIBEIRO J., ROUSSELLE J., TRUNG H.T., 2000. Application of diffusion processes to runoff estimation. J. Hydrol. Eng., 5, 1-7.

LAUZON N., 1995. Méthodes de validation et de prévision à court terme des apports naturels. Mémoire de maîtrise, École Polytechnique, Montréal, Québec, Canada.

LAUZON N., BIRIKUNDAVYI S., GIGNAC C., ROUSSELLE J., 1997. Comparaison de deux procédures d'amélioration des prévisions à court terme des apports naturels d'un modèle déterministe. Rev. Can. Génie Civ., 24, 723-735.

LEFEBVRE M., 2002a. Using a lognormal diffusion process to forecast river flows. Water Resour. Res. (À paraître)

LEFEBVRE M., 2002b. Geometric Brownian motion as a model for river flows. Hydrol. Process., 16, 1373-1381. 